\title{
The political legitimacy of company law and regulation
}

\author{
Daniel AtTenborough
}

\author{
Durham Law School
}

\begin{abstract}
Two interrelated objectives are pursued in this article: the first concerns the relationship and interaction between the UK's company law and market-based regulation; the second explores the legitimacy of marketbased regulation in light of its potential to mould and influence the substantive law. Although the article finds that the two systems retain carefully defined, essentially consistent and mutually complementary roles, it submits that market-based formations run the risk of not readily or plausibly lending themselves to dominant political and democratic accounts, which are deployed customarily to substantiate the legitimacy of state interventionist techniques. Simultaneously, the deployment of a rival conception of legitimacy, conceived as technocratic expertise and market consensus and conformity, is problematic for a number of theoretical and practical reasons. This has implications for the effects and outcomes of the UK's company law and governance.
\end{abstract}

Keywords: company law; corporate law; market regulation; regulatory theory

\section{Introduction}

$\mathrm{T}$

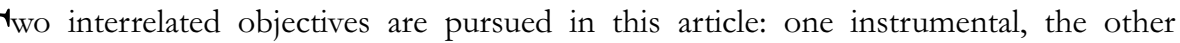
substantive. The narrow objective is to address a question that has attracted very little attention in company law scholarship, ${ }^{1}$ although it is, it must be said, of considerable theoretical, and potentially also some practical, importance in respect of the direction and control of companies listed on the London Stock Exchange. The question concerns the interaction between substantive company law and market-based regulation. Does UK company law and market-based regulation work together as, in some sense, a single coherent, integral body of rulemaking, or do they constitute two separate entities, two streams running on parallel lines, one of which occasionally feeds the other, but which are

* Associate Professor in Corporate Law, Durham University. Earlier versions of this article were presented at the 2016 Annual Conference of the Society of Legal Scholars at the University of Oxford, and at seminars in Manchester University, University College London and University of California, Berkeley. I am thankful for the extremely helpful comments and suggestions received from participants at these events, and especially to Marc Moore, Paul O'Connell, Gavin Phillipson, Chris Riley and Alexander Williams. The usual disclaimers apply. Also, a significant part of this work was undertaken while I was at the University of California, Berkeley, to which I am grateful for providing a productive and stimulating working environment.

1 Virtually the only partially related discussion of which the author is aware is in D Kershaw, 'Corporate Law and Self-Regulation' in J N Gordon and W G Ringe (eds), The Oxford Handbook of Corporate Law and Governance (Oxford University Press 2018) 869. 
destined for ever to retain their separate roles? In posing this question, it must be made clear that we are not concerned with the question of how well law and regulation fit together, but with the logically prior question of how they fit together. It is trite that large areas of both the law and market-based regulation are problematic, but is it one problematic area or are there two? This may seem a rather theoretical, or even metaphysical, question. Yet, there are a number of important practical issues involved here, in the sense that market-based regulation is a dynamic, developing body of rules and norms just as much as legal doctrines and legal decisions are, and the way in which they map onto each other becomes a matter of no little importance. ${ }^{2}$ The most empirically significant regulatory formations on which we focus are: the Corporate Governance Code, the Listing Rules and Listing Requirements, and the Takeover Code.

While there is in one respect no neat dividing line between substantive law and market regulation, ${ }^{3}$ the two species of rules remain distinguishable. ${ }^{4}$ First and foremost, companies' legislation and the courts today function to generate higher order rules that set out a template for the processes and constraints of the formation and continuing regulation of companies during their lifecycle. Second, over the past several decades substantive company law has, in different shapes, focused on managing and containing the problem of managerial agency costs: the economic costs incurred when managers act in their own, not the shareholders' interests. Notwithstanding, in targeted areas of socially sub-optimal behaviour and outcomes the longstanding British regulatory style has created a presumptive view that market participants are entitled to generate and enforce lower order regulation to resolve the problems of their own making. Even where the state is actively responsible for rule design and enforcement, sometimes the law has remained curiously indeterminate. On this basis, market regulatory forms have the potential to mould and influence the substantive content of that law. Properly understood as facilitating productivity organised in companies by reducing suboptimal market behaviour and managerial agency costs, these regulatory devices purport to maintain an exclusive focus 'on the (functional) means rather than (normative) ends of purportedly efficient boardroom practices'. ${ }^{5}$ However, the regulator constituencies tend in practice to embody a 'common investor-protectionist ethos, and corresponding disregard for public policy concerns extraneous to considerations of shareholder welfare'. 6 Although this practical

2 M Petrin, 'Regulatory Analysis in Corporate Law' (2016) 79(4) Modern Law Review 537, 529. See also, P L Davies, 'Corporate Boards in the United Kingdom' in P Davies, K Hopt, R Nowark and G von Solinge (eds), Corporate Boards in Law and Practice: A Comparative Analysis in Europe (Oxford University Press 2014) 713, 773.

3 An early example that covers the main arguments along jurisprudential lines can be found in J Raz, 'Legal Principles and the Limits of Law' (1972) 81(5) Yale Law Journal 823. For a more recent example focused specifically on corporate regulation, see E Ferran, 'Corporate Law, Codes and Social Norms - Finding the Right Regulatory Combination and Institutional Structure’ (2001) 1(2) Journal of Corporate Law Studies 381, 382 and 386-390.

4 It is submitted that the ideological conservatism, enumerated by the likes of Ferran (n 3), can be viewed as symptomatic of a discipline trying to face up to a new and rapidly changing scene. Conversely, there is a genuine intellectual concern, forcefully articulated by Simon Roberts, that lumping together state law and diverse forms of delegated law obscures the distinctiveness of centralised forms of governance and lets blinkered lawyers in to view other forms of normative ordering through distorted lenses. On this point, see S Roberts, 'Against Legal Pluralism: Some Reflections on the Contemporary Enlargement of the Legal Domain' (1998) 42 Journal of Legal Pluralism 95; S Roberts, ‘After Government? On Representing Law without the State' (2005) 68 Modern Law Review 1. See also, W Twining, General Jurisprudence: Understanding Law from a Global Perspective (Cambridge University Press 2009) 371-375.

5 M Moore, Corporate Governance in the Shadow of the State (Hart 2013) 172.

6 Ibid. This is discussed further in section 3. 
understanding includes and is consistent with company law's shareholder prioritisation, a question mark is raised about its compatibility with company law's shareholder weighting. Specifying, market-based regulation portends to structure and amplify shareholder interests and value pressures (relative to the UK's substantive company law-making bodies), which risks further reducing management insulation from shareholder value pressures.

Typically, the way in which companies are governed, and the way such governance is perceived, contributes inexorably to the political legitimacy of corporate control, and this legitimacy underpins both the acceptance and the effects of corporate activity. From the perspective of orthodox political narratives and democratic criteria, Parliamentary lawmaking derives a substantial part of its procedural and substantive legitimacy from sovereign prerogative, processes of consensual democracy, and accountability to the courts. Similar thinking can be applied to the court's role, which is to apply the prescriptions of the legislature, or the established principles deduced from a series of precedents, to individual disputes. Yet, an equivalent narrative for today's market-based regulation is less straightforward when it encounters and interacts with state-legitimacy pressures. These dynamic and semi-autonomous rule-systems, which are often thought to derive survival and legitimacy from rival notions of 'neutral-technocratic' expertise and market consensus, ${ }^{7}$ tend to reclassify acts conventionally regarded 'public' and 'political' as 'commercial', 'private' and, therefore, properly 'legal'. 8 This approach leads the article to a second, and broader, question: does market-based regulation retain a firm basis on which to rest its continuing legitimacy? The obvious tension in this regard is that 'these authorities, or some of them at least, wield significant powers which may be abused to the detriment of their own members, third parties or the public at large: they may be exploited, or their interests may be otherwise insufficiently taken into account'. 'This article foregrounds this tension between company law and market-based regulatory legitimacy and examines the strength of the case for the possibility of market-based regulation obscuring the basic principles of law around which that regulation has developed.

\section{The role and limits of UK company law}

In order to make sense of the question of legal-regulatory 'fit', it is necessary to identify the content and purpose of the UK's company law. Functionalist accounts of a particular set of legal rules focus typically on the purposes served for society by the rules in question. ${ }^{10}$ In this regard, company law's role is to provide continuing 'rules of the game' to facilitate and control the activities of business associations during their lifecycle. A functionalist understanding, accordingly, seeks to explain how the system of company law achieves this end. ${ }^{11}$ First and foremost, its legal framework primarily enables the structuring of economic power of businesses that 'incorporate' to secure such advantages as convenience, financial flexibility and limited liability. ${ }^{12}$ For example, company law

7 Moore (n 5) 170-171.

8 F Vibert, The Rise of the Unelected: Democracy and the New Separation of Powers (Cambridge University Press 2007) 9-10.

9 A C Page, 'Self-Regulation: The Constitutional Dimension' (1986) 49(2) Modern Law Review 141, 142.

10 J Armour, 'Who Should Make Corporate Law? EC Legislation Versus Regulatory Competition' (2006) 58(1) Current Legal Problems 369, 371-373. For a similar account of US corporate law, see M A Eisenberg, 'The Architecture of American Corporate Law: Facilitation and Regulation' (2005) 2(1) Berkley Business Law Journal 167, 169.

11 Armour (n 10).

12 See e.g. R H Coase, 'The Nature of the Firm' (1937) 4(16) Economica 386. 
establishes the structure of the corporate form, which acts as an incentive to organise productivity and plays a critical role in promoting enterprise and investment. Other examples, of the many in which the law designs basic 'nuts and bolts' of productivity organised in companies, include: the corporate constitution, corporate governance issues (including the directors' role, duties and responsibilities), as well as shareholder remedies, the protection of creditors, and directors' liabilities on insolvency. As a second-order objective - and one that flows from the use of the corporate form - company law plays an important role in mediating the principal-agent conflict between the company's shareholders and its hired directors. This assures that the directors are responsive to the shareholders' interests rather than pursuing their own personal interests. ${ }^{13}$ Minimising agency costs is achieved through regulatory strategies that prescribe substantive terms that govern the content of the principal-agent relationship, tending to constrain, either directly or in practice, the directors' behaviour ${ }^{14}$ and governance strategies that seek to facilitate the shareholders' empowerment and control over managerial behaviour. ${ }^{15}$ Ultimately, the UK's legal ecology directly or indirectly assigns priority interest to the company's shareholders relative to other affected parties in the effective functioning of wealth-generating companies.

Notwithstanding, the UK corporate legal order does not address every aspect of business activity. In particular, the government has, as a historical matter, sometimes considered it more expedient to defer to market mechanisms to constrain opportunistic behaviour, excessive risk-taking and other socially undesirable behaviour. ${ }^{16}$ When the substantive law must address, and historically has addressed, the doctrinal minutiae of business regulation and, in particular, the radical or game-changing questions central to company law and policy, its rules and decisions are not, of necessity, at the same time, doctrinally dispositive. While the limits of legal rules are almost inevitable in most living areas of law, it is most conspicuous in the corporate context in tensions, explained above, between the company's shareholders and its hired directors. The UK's principal company law is, of course, the Companies Act 2006, which - like all legislation - is a product of the political processes and is thus subject to representative democratic criteria and popular accountability. ${ }^{17}$ An Act of Parliament, once established, is often a trade-off

13 The most influential paper on this subject is M Jensen and W Meckling, 'Managerial Behaviour, Agency Costs and Ownership Structure' (1976) 3 Journal of Financial Economics 305.

14 See the Companies Act (CA) 2006, ss 170-177. In particular, s 172(1) makes clear that shareholders are now the intended beneficiaries of corporate productivity and enjoy relative priority under varying circumstances. As provided for under Companies Act 2006, ss 260-264, shareholders have the right to initiate proceedings on behalf of the company for breaches of directors' general fiduciary duties.

15 The shareholders in general meeting retain residual and ultimate decision-making power through statute and common law. For example, under the Companies Act 2006, shareholders have the right to vote on the amendment of the articles of association (ss 33 and 21), approval for all economically significant corporate transactions (ss 177, 182, 190-196), mandatory access to the proxy card (ss 303, 314-317, 338-340), antidilution rights (ss 171, 549-551, 561-563), and so forth. What is more, shareholders retain the important entitlement to remove directors 'without cause' under Companies Act 2006, s 168. Shareholders are also formally empowered (concurrently with the board itself) to appoint new directors by way of ordinary resolution under the company's articles, although this default rule is formally subject to variation by individual companies. However, in the case of Premium Listed companies it is reinforced by the express UK Corporate Governance Code requirement - applicable on a 'comply or explain' basis - that directors be (re)elected by shareholders, which in larger FTSE 350 companies at least should take place on an annual basis. See Financial Reporting Council, UK Corporate Governance Code (July 2018), Code Provision 3.18 <www.frc.org.uk/getattachment/88bd8c45-50ea-4841-95b0-d2f4f48069a2/2018-UK-CorporateGovernance-Code-FINAL.PDF>.

16 This will be discussed in section 3.

17 On this point, see D Feldman, 'Preface' in D Feldman (ed), Law in Politics, Politics in Law (Hart 2014) I. 
between, on the one hand, distinct practical and political constraints and, on the other, what the legislature intended. This arrangement inevitably gives rise to the articulation of conservative and/or indeterminate legal rules. ${ }^{18}$ Simultaneously, the English courts have a general obligation in construing statutes to make law that effectuates legislative purpose. ${ }^{19}$ Where the legislative purpose is extremely vague or the delegation of the lawmaking power to the courts broad, the courts' interpretative role proceeds as a circumscribed formalistic style of legal reasoning. ${ }^{20}$ In this regard, the general obligation of the courts is to interpret and apply rigidly the prescriptions of the legislature, or the generalised principles deduced from a series of precedents, to individual disputes, which must be fitted into the existing body of the law. ${ }^{21}$

Ultimately, the ingrained legislative conservatism and formalistic climate of the common law, taken together, are likely to have a dampening effect on the perceived impact of company law's weighted shareholder presence. The following examples provide merely a flavour of the limits of the common law tradition, and of statute, in this practical and real-world sense. First, when we think about the perennial questions central to corporate theory, it is impossible to avoid the uncertainty in law about the nature of ownership and control in publicly listed companies. ${ }^{22}$ Second, perhaps the clearest expression of company law's ambiguity regarding the intended beneficiaries of corporate production is the fact that directors are required under the duty of good faith to act in the honest belief that their action was taken, simultaneously, in the best interests of the shareholders and the company itself. ${ }^{23}$ Third, this analytical frame of reference could be extended to the directors' general company law duty of care and skill. ${ }^{24}$ In spite of receiving close judicial and scholarly attention in the 1990s, and again during the most recent company law reform project, the duty is incomplete in the sense that the limited case law means it is difficult to know what amounts to a careful process and what is to be expected of directors in order to determine what a typical careful director performing the

18 Some of the scholarly writing on the most recent company law reform project seems to chime with this point. See e.g. S Worthington, 'Reforming Directors' Duties’ (2001) 64(3) Modern Law Review 439, 458; R Goddard, “"Modernising Company Law": The Government's White Paper' (2003) 66(3) Modern Law Review 402, 423.

19 Since the enactment of the Companies Act 2006, much of UK company law is now the preserve of statute law, and the instances of the courts' statutory construction of extant companies' legislation are voluminous. For general academic support on this point, see e.g. H L A Hart, The Concept of Law (2nd edn, Clarendon 1994) 132-133; H R Hahlo, 'Here Lies the Common Law: Rest in Peace' (1967) 30 Modern Law Review 241, 248.

20 M J Whincop, An Economic and Jurisprudential Genealogy of Corporate Law (Ashgate 2001) 2. For an informative account of the altogether more policy-oriented jurisprudential traditions of the US courts, see E B Rock, 'Corporate Law Doctrine and the Legacy of American Legal Realism' (2015) 163 University of Pennsylvania Law Review 2019.

21 See H L A Hart, 'American Jurisprudence through English Eyes: The Nightmare and the Noble Dream' (1977) 11 Georgia Law Review 969, 979. See also, T Allan, 'Questions of Legality and Legitimacy: Form and Substance in British Constitutionalism' (2011) 9 International Constitutional Law Journal 155, 185; W Friedman, 'Limits of Judicial Lawmaking and Prospective Overruling' (1966) 29(6) Modern Law Review 593, 595.

22 For an excellent exposition, and critique, of share 'ownership' as a doctrinal basis for the shareholders' role in corporate governance, see P Ireland, 'Company Law and the Myth of Shareholder Ownership' (1999) 62(1) Modern Law Review 32. For earlier noises about the unsatisfactory legal conception of share ownership, see A A Berle, 'Modern Functions of the Corporate System' (1962) 62 Columbia Law Review 433, 448.

23 Companies Act 2006, ss 170 and 172(1). For a detailed and nuanced analysis of the distinction between a shareholder-first idea and the pre-2006 common law articulation of the company's interests, see D Attenborough, 'Misreading the Fiduciary Duty of Good Faith' (2020 forthcoming) 20(1) Journal of Corporate Law Studies.

24 Section 174 of the Companies Act 2006. 
role would do. ${ }^{25}$ Fourth, the ex ante disciplinary options for shareholders, which are exercised in general meetings, tend to be practically limited in the case of publicly listed companies, ${ }^{26}$ where enforcement options typically give way to ex ante monitoring by outside directors and institutional shareholders. ${ }^{27}$ Fifth and finally, the statutory derivative claim procedure, which notionally allows a shareholder to bring a legal action on the company's behalf in order to remedy wrongs done to it, specifies permission/leave barriers that shareholders are unlikely to overcome, thereby creating little incentive to litigate. ${ }^{28}$

\section{The relationship between law and regulation}

Due to powerful political and economic priorities, the majority of which were driven over several decades by globalisation and a neoliberal order, ${ }^{29}$ the dominant trend in world affairs has been the 'disaggregation of power into myriad spheres of authority' to facilitate market-based 'norms, informal rules and regimes. ${ }^{30}$ On this basis, the state retains a residual role in delineating the contours of companies' regulation, but then 'commands' the market into filling in the substantive content of that regulation. ${ }^{31}$ It is commonly regarded, mainly from within the field of neoclassical economics, ${ }^{32}$ as a more efficient rule-making approach, as against the perceived deficiencies of state-promulgated law, ${ }^{33}$ based upon the overarching theory of 'reflexive law'. ${ }^{34}$ At its heart, reflexive law seeks to mobilise the integrative capacities of the markets and institutions outside the legal system to control companies' adverse socio-economic behaviour in the marketplace.

25 On the marginal or peripheral role of the directors' duty of care after the 2008 global financial crisis, see M Moore, 'Redressing Risk Oversight Failure in UK and US Listed Companies: Lessons from the Citigroup and RBS Litigation' (2017) 18 European Business Organization Law Review 733. For an earlier example from the US, which fundamentally centres on the limits of the duty of loyalty and the duty of care, see J Seligman, 'The New Corporate Law' (1993) 59(1) Brooklyn Law Review 1.

26 A prime example is the mandatory 'without cause' removal right under Companies Act 2006, s 168. But see, L E Strine, 'The Soviet Constitution Problem in Comparative Corporate Law: Testing the Proposition that European Corporate Law is More Stockholder Focused than US Corporate Law' (2016) 89 Southern California Law Review 1239. See also, D Attenborough, 'The Vacuous Concept of Shareholder Voting Rights' (2013) 14(2) European Business Organization Law Review 147; A R Keay, 'Company Directors Behaving Poorly: Disciplinary Options for Shareholders’ [2007] Journal of Business Law 656.

27 M Gelter and G Helleringer, 'Corporate Opportunities in the US and the UK: How Differences in Enforcement Explain Differences in Substantive Fiduciary Duties' in D Gordon Smith and A S Gold (eds), Research Handbook on Fiduciary Law (Edward Elgar 2018) 331.

28 On the infrequent use of the regime, see A R Keay, 'Assessing and Rethinking the Statutory Scheme for Derivative Actions under the Companies Act 2006' (2016) 16(1) Journal of Corporate Law Studies 39, 41.

29 For some useful critical works on neoliberalism, see R Plant, The Neoliberal State (Oxford University Press 2010); D Harvey, A Brief History of Neoliberalism (Oxford University Press 2007); N Chomsky, Profit Over People: Neoliberalism and Global Order (Seven Stories Press 1998).

30 J N Rosenau, 'Governing the Ungovernable: The Challenge of a Global Disaggregation of Authority' (2007) 1(1) Regulation and Governance 88, 88. See also, S Picciotto, 'Constitutionalizing Multilevel Governance?' (2008) 6(3) International Journal of Constitutional Law 457; B Lange, 'Regulatory Spaces and Interactions: An Introduction' (2003) 12(4) Social and Legal Studies 411, 413.

31 This definition follows closely the one provided in Kershaw (n 1), Part IV. It can be contrasted with 'selfregulation', which, as Julia Black has remarked, implies no particular relationship with the state. See J Black, 'Constitutionalising Self-Regulation' (1989) 59(1) Modern Law Review 24, 27.

32 See e.g. C Sunstein, 'The Paradoxes of Regulation' (1990) 67 University of Chicago Law Review 408.

33 J Black, 'Paradoxes and Failures: ‘New Governance Techniques and the Financial Crisis' (2012) 75(6) Modern Law Review 1037, 1038.

34 The pioneering article is G Teubner, 'Substantive and Reflexive Elements of Modern Law' (1983) 17 Law and Society Review 239. See also, G Teubner, Law as an Autopoietic System (Blackwells 1993) at ch 5; R M Unger, 'Legal Analysis as Institutional Imagination' (1996) 59(1) Modern Law Review 1. 
There are powerful economic arguments for the application of reflexive law strategies to corporate regulation, ${ }^{35}$ which cohere to political theories rooted in autonomy and the promotion of individual freedom of choice - and, importantly, while implicating some kind of normative commitment, do not rely on the imposition of binding standards or on a regime of formal sanctions. ${ }^{36}$

Placed in historical context, the UK's Parliament has consciously and deliberately entrusted certain important rule design and enforcement responsibilities to market-based regulatory regimes. ${ }^{37}$ These regulatory forms are customarily regarded as hybrid state/market bodies, which provide scope for flexibility, diversity and opt-out at the point of intra-corporate application. ${ }^{38}$ While these alternative mechanism diverge considerably in micro-institutional identities and drivers, these lower order rule-sets reveal two ultimate and coherent functions for society. This common purpose, to a large extent, complements the abovementioned role and function of the higher order rules of company law. The UK's market-based regulation attempts in general to leverage the market's knowledge and information advantages to coordinate and enforce the 'rules of the game' governing the rights, relations and conduct of, and within, listed companies whose shares are admitted to trading on the London Stock Exchange. ${ }^{39}$ Second, it is in general designed to protect the integrity of the UK equity markets from market misconduct in order to mitigate the information asymmetry problems and agency costs incurred by shareholders in listed companies. ${ }^{40}$ The interests of other socio-economic market participants extraneous to considerations of shareholder welfare are in general of secondary importance. ${ }^{41}$ No doubt, it would be inaccurate to suppose that company law does not 'matter' in some way to the background state of legal normality against which many areas of corporate life take place. However, market-based solutions have emerged to help increasingly structure and coordinate productivity organised in companies.

This regulatory impact is most evident where, as explained above, Parliament has deferred law-making competence to the market because it neither has the time, nor the interest, nor the expertise. Yet, it is also the case where there is proactive intervention or a role for law central to the control and enforcement of socially suboptimal behaviour, but which the legal rules in question are articulated in only the barest form. Framing important legal questions and issues around seemingly indeterminate legal doctrines and legal decisions is thus often, and understandably, somewhat limited in effectiveness and

35 On this point, see e.g. Teubner, 'Substantive and Reflexive Elements' (n 34).

36 The classic accounts of Hayek's distinction between constructed legal rules and decentralised law are: F Hayek, Law, Legislation and Liberty (Routledge 1973) 72-91; F Hayek, The Road to Serfdom (Routledge 1944) 75-90. Compare the work of legal realist scholars who, nearly a century ago, revealed the public legal underpinnings of private economic power. See e.g. M R Cohen, 'Property and Sovereignty' (1927) 13 Cornell Law Review 8.

37 See e.g. A Fox, History and Heritage: The Social Origins of the British Industrial Relations System (Allen \& Unwin 1985).

38 Moore (n 5) 167.

39 Kershaw (n 1) 869.

40 Lord Alexander of Weedon, 'Judicial Review and City Regulators' (1989) 52 Modern Law Review 640, 647; B R Cheffins, Company Law: Theory, Structure and Operation (Oxford University Press 1997) 18.

41 For example, not all concerned parties necessarily have input into the formulation of market-based regulatory products. To some extent, this deficit can be addressed through appropriate consultative processes by standard-setting bodies. However, perhaps because of a common investor-protectionist ethos of these regulatory bodies, transparency or participation for non-members has not typically been a priority. In a similar way, the rights of citizens are indirectly affected by, say, the Takeover Panel's decisions and, arguably, only those owning securities may in a technical sense be said to have assented to the situation. On this second point, see $R v$ Panel on Takeovers and Mergers, ex parte Datafin [1987] 2 WLR 699, as per Lord Donaldson MR at 838. 
outlook. Importantly, in order to interpret and apply the rules in question, it might be tempting for policymakers or practitioners to draw upon more workable and consistent criteria set forth in market-based regulation. These alternative sources have the potential to be used to identify the functions, and context-specific expectations, of directors when fleshing out what should be or should not be done. For our purposes, therefore, marketbased rule production might be used not simply as 'an affair of technical bureaucratic minutiae, the thrust and parry of setting agendas, framing issues, and deciding priorities', 42 but also to "manage the tensions between the "social" and "economic" goals of modern democracies, tensions that enflame passionate and highly wrought political conflict over the ethical limits of global capitalism'. ${ }^{43}$ There is already some evidence of such an approach. Accordingly, what follows is a brief outline of the UK's empirically significant market-based regulatory creations, but only to the extent necessary to explain the substantive area they are regulating and the interaction with the substantive law. More will be said later in the article about the institutional arrangements of market-based forms and how their relationship to the state, and their legitimacy, is calibrated through these arrangements.

\subsection{The Corporate Governance Code}

The Corporate Governance Code of the Financial Reporting Council (FRC) applies, on a 'comply or explain' basis, ${ }^{44}$ to all companies that have their shares publicly quoted in the UK. ${ }^{45}$ First introduced in 1992, it goes further than closely reflecting existing boardroom practices and has, for example, shifted incrementally, then radically, board composition and separation practices. In the absence of direct attention by UK company law, ${ }^{46}$ the Code has been primarily concerned with providing independent governance recommendations that address the structure and function of the board as a disciplinary device. It addresses, in particular, corporate culture; the division of executive and nonexecutive directors; board and committee structure and staffing of these committees; remuneration guidance; and internal controls. ${ }^{47}$ Although the latest version now provides, for the first time since its inception, regulatory recognition of the importance of nonshareholder corporate stakeholders, ${ }^{48}$ a pro-shareholder regulatory residue arguably remains an important stimulus of how the FRC understands its role in the corporate

42 B Morgan, 'The Economization of Politics: Meta-Regulation as a Form of Nonjudicial Legality' (2003) 12(4) Social and Legal Studies 489, 490.

43 Ibid.

44 The Listing Rules and Listing Requirements reinforce the Code's voluntary status. See Listing Rules 9.8.6(5)9.8.6(6).

45 See UK Corporate Governance Code <www.frc.org.uk/getattachment/88bd8c45-50ea-4841-95b0d2f4f48069a2/2018-UK-Corporate-Governance-Code-FINAL.pdf>.

46 Although the Companies Act 2006 stipulates the minimum number, and age, of directors in a public or private company, the statute remains silent on internal governance arrangements generally, preferring instead to leave such matters to be decided at the intra-firm level.

47 The Corporate Governance Code 2018, ss 1-5.

48 The 2018 version of the Code essentially takes its lead from the Green Paper consultation on Corporate Governance: BEIS, Corporate Governance Reform (November 2016). See e.g. The Corporate Governance Code 2018, 'Introduction'. 
governance edifice. ${ }^{49}$ Consider, for example, the continuing importance attached to the views of major shareholders in respect to governance and performance, ${ }^{50}$ the senior nonexecutive director's role as intermediary for the other directors and shareholders, 51 and the various sub-committees' main role and responsibility to provide pertinent information to, or engage with, shareholders collectively. ${ }^{52}$ Furthermore, while listed companies have no choice but to comply with the Code, they can choose to adopt a different approach if that is more appropriate to their circumstances. Where they do so, however, they are required to explain the reason, through their annual report, to the markets generally and, in particular, their shareholders, who assess and respond to non-compliance through the credible threat of 'voice' or 'exit'. 53 The Code thus facilitates agency cost-reducing mechanisms designed to engender investor empowerment and investor confidence in the board's activities and contributions by increasing the accountability of directors to sharebolders. ${ }^{54}$ Although nothing in the Code overrides or is intended as an interpretation of directors' duties, its weighted shareholder presence has already influenced the courts' interpretive role in various cases. For example, recent case law has begun to use market-based criteria about a director's function and role in order to understand the substantive expectations generated by the duty of care obligation. ${ }^{55}$ Similarly, directors in the UK are customarily focused on shareholder value through higher share prices, and an apparent benefit of complying with the Code is an optimal (or at least relatively high) share price. ${ }^{56}$

\subsection{The Listing Rules and Listing ReQuirements}

A company must adhere to the Listing Rules and Listing Requirements of the Financial Conduct Authority (FCA) in order to maintain a full listing on the London Stock Exchange. ${ }^{57}$ This financial regulatory device encompasses a set of market-based, but contractually supported, obligations applied to premium listed companies, and is subject to the oversight of the UK Listing Authority. In some sense the primary focus of the Listing Rules on ensuring the integrity of financial markets and capital formation might be viewed as having a public policy effect because an increasing amount of the

49 Of course, since 2014 the Code has instructed boards 'to present a fair, balanced and understandable assessment of the company's position', the so-called 'viability statement', which might be regarded as permitting creditors and suppliers to companies to assure themselves of getting a return on their investment. However, the presumptive recipients of the audit, risk and internal control recommendations are primarily the company's shareholders, a fact that is reflected in the Code's express stipulation that this information, set forth in the annual report, 'is necessary for shareholders to assess the company's position, performance, business model and strategy'. See The Corporate Governance Code 2018, 4.26-27.

50 Ibid 1.3.

51 Ibid,2.12.

52 Ibid e.g. $4.25,4.27,5.41$.

53 On the relative effectiveness of controlling management in this regard, see e.g. J Parkinson, 'The Role of "Exit" and "Voice" in Corporate Governance' in S Sheikh and W Rees (eds), Corporate Governance and Corporate Control (Cavendish 1995) ch 3.

54 The Cadbury Report, The Financial Aspects of Corporate Governance $<$ www.ecgi.org/codes/documents/cadbury.pdf>.

55 Perhaps the most prominent example can be found in Secretary of State for Trade and Industry v Baker (Re Barings) [1999] 1 BCLC 433. In the Australian context, see Australian Securities and Investments Commission v Rich 44 ACSR 431 (2003); ASIC v Healey 278 ALR 618 (2011).

56 A Keay, “'Comply or Explain” in Corporate Governance Codes: In Need of Greater Regulatory Oversight?' (2014) 34(2) Legal Studies 279, 283.

57 See UK Listing Rules <www.handbook.fca.org.uk/handbook/LR.pdf>. For an indepth discussion and analysis of the Listing Rules and Listing Requirements, see generally E Ferran and L Chan Ho, Principles of Corporate Finance Law (2nd edn, Oxford University Press 2014) ch 13. 
population's non-occupational income provision now relies on equity markets. ${ }^{58}$ However, it is today the investment intermediaries, rather than ultimate contributors to equity, which have become putative stewards over corporate governance. This growth of intermediation has led primarily to an increased potential for misaligned incentives and a tendency to view market effectiveness through the eyes of intermediaries. ${ }^{59}$ Against this backdrop, the Listing Rules contain a number of central corporate governance rules and the 'comply-or-explain' obligation underlying the Corporate Governance Code is also to be found there. The current rules contain six overarching 'Listing Principles', as well as detailed continuing obligation rules in areas such as regulatory notifications, ${ }^{60}$ annual financial reports ${ }^{61}$ and corporate governance. ${ }^{62}$ The basic control is ex ante disclosure to the markets generally and the company's shareholders specifically, on which it is incumbent to determine whether the response of the company to the Listing Rules does enough and then take some action if they do not. For example, financial information must be disclosed to domestic and overseas investors in order to assist them to make active and properly informed decisions about a company's financial position and ensure the pricing of shares in the market is based on adequate and accurate information. In Listing Rule 10, moreover, shareholder approval is imposed exogenously on all economically significant transactions. ${ }^{63}$ Because shareholder voting is mandatory and binding, rather than a choice variable of the board or management, it acts as a practically effective lever of board accountability. Ultimately, while the Listing Rules, until relatively recently, had a much more direct impact on the terms of a listed company's constitution, ${ }^{64}$ these rules have, over the years, driven the terms of engagement between a listed company and its shareholders. ${ }^{65}$

\subsection{THE TAKeOVER CODE}

For directors of UK listed, or widely held private, companies that are involved in changes of corporate control, the Takeover Code provides the main domestic regulatory framework. ${ }^{66}$ The application of the rules is reinforced mainly by the threat of reputational administrative sanctions for non-compliance, with only limited available

58 On this generally, see M Gelter, 'The Pension System and the Rise of Shareholder Primacy' (2013) 43 Seton Hall Law Review 909, 911. For earlier and similar thinking on this issue, see A A Berle, 'For Whom Corporate Managers are Trustees: A Note' (1932) 45 Harvard Law Review 1365, 1368.

$59 \mathrm{~J}$ Kay, The Kay Review of UK Equity Markets and Long Term Decision Making (2012) Executive Summary, point x <https://assets.publishing.service.gov.uk/government/uploads/system/uploads/attachment_data/file/2534 54/bis-12-917-kay-review-of-equity-markets-final-report.pdf>. See also, R J Gilson and J N Gordon, 'The Agency Costs of Agency Capitalism: Activist Investors and the Revaluation of Governance Rights' (2013) 113 Columbia Law Review 863.

60 Listing Rules 9.6 and 15.6.

61 Listing Rule 9.8.

62 Listing Rules (mainly) 7, 9, and 15.

63 But also in the case of all UK-registered companies, see the Companies Act 2006, ss 177, 182 and 190-196.

64 R Nolan, 'The Continuing Evolution of Shareholder Governance' (2006) 65(1) Cambridge Law Journal 92, 112.

65 I MacNeil and A Lau, 'International Corporate Regulation: Listing Rules and Overseas Companies' (2001) 50 International and Comparative Law Quarterly 787. On the continuing importance of Listing Rule 10, see M Becht, A Polo and S Rossi, 'Does Mandatory Shareholder Voting Prevent Bad Acquisitions?' (2016) Review of Financial Studies 29(11) 3035.

66 See the Takeover Code

<www.thetakeoverpanel.org.uk/wp-content/uploads/2008/11/code.pdf?v=1Apr2019>.

On the historical origins and early development of the Takeover Code, see D Kershaw, Principles of Takeover Regulation (Oxford University Press 2016); A Johnston, The City Takeover Code (Oxford University Press 1980). 
recourse to the courts. ${ }^{67}$ Although the Code has been amended over time since its inception, its central provisions have not been altered in substance. Today's Code is an interventionist and onerous body of six general principles and more specific supplementary rules, which proceed on the basis of ensuring the efficiency and procedural fairness of a bid from the perspective of the shareholders. ${ }^{68}$ In the wake of Kraft's takeover of Cadbury in 2010, ${ }^{69}$ the views of employees now receive some prominence, ${ }^{70}$ but such changes in general remain 'a halfway house'. ${ }^{71}$ Properly understood, the Code remains 'ambivalent regarding the treatment of non-shareholder stakeholders'. ${ }^{72}$ Against this pro-shareholder backdrop, the most important obligations of the Code's provisions include: the requirement of similar treatment of shareholders of a particular class, ${ }^{73}$ the requirement of full and accurate information for shareholders ${ }^{74}$ and the avoidance of a false market, which is sought through requiring full disclosure of transactions to the company's shareholders. ${ }^{75}$ One cannot underestimate the fact, moreover, that shareholders collectively are entitled to exercise the final 'say' over the outcome of a contested takeover bid by virtue of the so-called 'board neutrality' rule. ${ }^{76}$ This managerial authority-limiting rule is a powerful driver of an open market for corporate control, which is customarily regarded as a core mechanism for aligning directors' interests with those of the company's shareholders. ${ }^{77}$ Andrew Johnston observed in this regard that the Code's priorities 'reflect the fact that, historically, the primary concern of the drafters of the Code was to maintain investor confidence in the City rather than to improve standards of corporate governance generally [emphasis added]'. ${ }^{78}$

67 L Hilliard, 'The Takeover Panel and the Courts' (1987) 50 Modern Law Review 372, 378, remarking that, '[d]espite the potentially wide ambit of Datafin, clearly in future the courts will not wish to supervise the activities of every decision-making body in the country'. Support for this point is found in an excellent analysis of the law in Black (n 31) 32-43.

68 For an academic commentary, see J Armour and D Skeel, 'Who Writes the Rules for Hostile Takeovers, and Why?' The Peculiar Divergence of US and US Takeover Regulation' (2007) 95 Georgetown Law Journal 1727, 1730 .

69 B Morris, 'The Cadbury Deal: How it Changed Takeovers' (BBC News, 2 May 2014) $<$ www.bbc.co.uk/news/business-27258143>.

70 City Code on Takeovers and Mergers, rules 2.7, 2.9, 20, 24, 25, and 30.

71 W Hutton, C Mayer and P Schneider, 'The Rights and Wrongs of Shareholder Rights' (2017) 40 Seattle University Law Review 375, 395.

72 L Rybak, 'Takeover Regulation and Inclusive Corporate Governance: A Social-Choice Theoretical Analysis' (2010) 10 Journal of Corporate Law Studies 407, 408.

73 City Code on Takeovers and Mergers, rule 11.1 (which fleshes out General Principle 1).

74 Ibid rule 21.3 (which fleshes out General Principle 2).

75 Ibid rule 2.2 (which fleshes out General Principle 4).

76 Ibid rule 21 (which fleshes out General Principle 3). Although company law's proper purpose doctrine, as set out under Companies Act 2006, s 171, provides purposive constraints on post-bid corporate action primarily intended to have a defensive effect, it does not, unlike rule 21, prohibit defences that have a defensive impact but which can be characterised as non-defensive business decisions. On this point, see D Kershaw, 'The Illusion of Importance: Reconsidering the UK's Takeover Defence Prohibition' (2007) 56 International and Comparative Law Quarterly 267, 289.

77 See e.g. H Manne, 'Mergers and the Market for Corporate Control' (1965) 73 Journal of Political Economy 110. What is more, the Takeover Code has, in its time, had an impact on the development of the common law. See, for example, Gething v Kilner [1972] 1 WLR 337; R v Panel on Takeovers and Mergers ex.parte Datafin plc [1987] 2 WLR 699; R v Panel on Takeovers and Mergers ex.parte Guiness [1989] 1 Sll ER 509.

78 A Johnston, 'Takeover Regulation: Historical and Theoretical Perspectives on the City Code' (2007) 66(2) Cambridge Law Journal 422, 451. It is important to note, however, that there exists wide disagreement about the nature and drivers of the Code. The literature on the Takeover Code has one strong view that institutional investors captured this regulatory space, while another looks to the influence of investment bankers. See, respectively, Armour and Skeel (n 68); Kershaw (n 66) ch. 3. 


\subsection{SUMMARY OF MARKET-BASED REGULATION}

On the article's first question about legal-regulatory 'fit', UK company law and marketbased rules, rather than being framed as antagonistic alternatives, or mutually exclusive directions of travel, work together in a number of core institutions of the UK's company law and governance, albeit with carefully defined, essentially consistent, and mutually complementary roles. These functions are to establish efficient building blocks of productivity organised in companies, understood as looking for rules and structures that maximise shareholder value by reducing the agency costs between directors and shareholders. However, this analysis poses in a conspicuous form the limits or edges of the law's effectiveness and outlook. This includes the context in which market mechanisms address areas of corporate activity that are clearly not covered by company law. Moreover, in other areas where both regulatory systems overlap in relation to their areas of rule production and enforcement, it is evident that the substantive law has sometimes remained curiously indeterminate. On this basis, at least in respect to listed companies, certain basic background rules of company law become little more than a rough 'freehand drawing' onto which the more dynamic and semi-autonomous marketbased regulation has the potential to 'paint' definition and colour as reflected in the expected preferences of advisors and their clients. If this is a plausible assessment of the likelihood of regulatory 'spread', then it is arguably clear that its normative and valueladen shareholder presence portends to structure and amplify shareholder interests and value pressures, which is likely to further reduce management insulation from shareholder value pressures. ${ }^{79}$ The main problem about market-based regulation in this regard is that it too readily transforms controversial objectives and political issues into questions of rulemaking for hybrid state/market regulators. In this way, it takes critical decisionmaking powers out of the political process. Since that process is the only way the general population is able to engage, however indirectly, in the shaping of law, this is arguably contentious from a democratic legitimacy perspective.

\section{On the political legitimacy question}

Following on from the analysis above, the second, and substantive, question to be addressed in this article centres on the idea that the way in which companies are governed, and the way such governance is perceived, contributes centrally to the political legitimacy and democratic accountability of companies' regulation and this underpins both the acceptance and the effects of corporate activity. At any time, an inquiry into the legitimacy and accountability of the regulator constituencies is worthwhile. However, the different ways in which alternative regulatory forms have come, either formally or in practice, to mould and influence the field of company law reveals a more pressing dimension. Accordingly, the question can be put as follows: do these ostensibly independent and apparently politically neutral-technocratic regulatory formations retain a firm basis on which to rest their continuing legitimacy? As this question immediately suggests, a great deal depends on how we understand the concept of law's 'legitimacy'. The organising principles of public law, namely, political and democratic theory, provide us with a useful framework for thinking about questions of legitimacy. This understanding tends to be deployed to explain or justify normatively the institutional legitimacy and deliberative quality of state interventionist functions. ${ }^{80}$ Although company

79 H Muir-Watt, 'Private International Law Beyond the Schism' (2011) 2 Transnational Legal Theory 347, 347.

80 There is a long list of works in this tradition; perhaps the most prominent examples include: R Dworkin, Taking Rights Seriously (Harvard University Press 1977); R Dworkin, Law's Empire (Harvard University Press 1986). See also, J Raz, Authority of Law (Oxford University Press 1979). 
law is not customarily characterised as an aspect of 'public' law, this approach is appropriate because a closer inspection reveals that much of the rulebook that affects the UK's system of company law is regulatory or 'non-private' in nature. ${ }^{81}$ It is emphasised, by way of a disclaimer, that this section does not seek to flesh out all aspects of the political legitimacy of law, which would not be possible in one article of limited length. At appropriate points the section identifies existing literature that provides further treatment.

\subsection{FRAMING THE RESEARCH ENQUIRY}

The first task, then, is to identify what we mean when we talk about democratic criteria or, more aptly, democratic theory, which is an established subfield of political theory. Without too great an over-simplification, the literature is concerned primarily with examining central descriptive questions about how policy or law is made and by whom, but also seeks to realise realistic normative accounts that show us the moderate standards to which we ought to be holding our law-making. Against a backdrop of relatively settled ideas about the rule of law and the separation of powers (especially the independence of the judiciary), explanations and predictions of democratic theory are typically diffused across a variety of academic disciplines and methodological orientations. Correspondingly, there exists broad disagreement about the relative importance of the notion of participation between, and amongst, the theories of earlier writers (the socalled 'classical theorists') ${ }^{82}$ and the more recent work (of 'liberal' social scientists). ${ }^{83}$ Generally speaking, early democratic theorists subscribe in the main to the view that the capacity for collective self-governance must be realised through participation, although one could infer that a delegation of sovereignty by the people to elected officials - as a 'second-best' - is invariably assumed. ${ }^{84}$ However, the typical starting point for more contemporary theories of democracy see little scope for full participation in the vast complexities of modern governance where technical competence, administrative expertise and executive decisions are needed. When viewed through the influential writing of Joseph Schumpeter, all that is entailed for democracy to work effectively is that enough citizens participate to keep the institutional arrangements working satisfactorily. ${ }^{85}$ The focus of his theory is, instead, on the minority of leaders, who must be active, initiate and decide, and it is competition between leaders for votes that is the characteristically democratic element in this political method. Whatever the differences between democratic criteria, all of these theories share a basic commitment to 'input-legitimate' governing processes, which are derived from the aggregate pluralistic preferences of the population at large, and that specific 'outputlegitimate' institutional arrangements are conducive to policy choices that are generally

81 See generally Moore (n 5); M Stokes, 'Company Law and Legal Theory' in W Twining (ed), Common Law and Legal Theory (Blackwell 1986) 155.

82 See the likes of J J Rousseau, The Social Contract, M W Cranston (trans) (Penguin 1967); J S Mill, Representative Government (Everyman 1910).

83 The most obvious example is J A Schumpeter, Capitalism, Socialism and Democracy (Allen \& Unwin 1943). An understanding of the nature of Schumpeter's theory is vital for an appreciation of more recent work in democratic theory, in which his established analytical framework and definition of democracy have all become almost universally accepted. More or less an example of this is R Dahl, After the Revolution? Authority in a Good Society (Yale University Press 1970).

84 C Pateman, Participation and Democratic Theory (Cambridge University Press 1976) 28 (discussing, in particular, the later work of J S Mill).

85 Schumpeter (n 83) 283. 
acceptable in terms of consensual notions of the public interest. ${ }^{86}$ The concepts of input and output-legitimacy, taken together, constitute the solidaristic prerequisites in debates about what makes substantive company law politically legitimate and democratically accountable.

\subsection{The POlitical Legitimacy OF LAW}

Typically, the UK's traditions of legal and political thought reflect the idea that:

... [m] uch of what legitimates [substantive] law and distinguishes it from other forms of normativity are the processes by which it is created and applied - adherence to legal process values, the ability of actors to participate and feel their influence, and the use of legal forms of reasoning [emphasis added]. ${ }^{87}$

Consider, for example, the UK's primary legislation relating to corporate activity, which is, it will be recalled, the Companies Act 2006. As a product of Parliamentary law-making, it derives a substantial part of its input-legitimacy from the formal elements of the rule of law, processes of consensual democracy, and the role of the courts as the ultimate authority on the meaning of legislation. Typically, when we think about how the rule of law supports and nourishes the legitimacy of the English legal system, we look at its restriction of the arbitrary exercise of power by subordinating it to well-defined and established laws that are publicly promulgated, equally enforced and independently adjudicated. The formal and procedural prerequisites of the rule of law are 'designed to ensure the authoritative legal rule is capable of ruling, and that is it is clear, prospective, general, relatively stable and so forth'. 88 On this account, the rule of law ensures corporate life or a substantive review of the corporate framework is ruled by law, order and (in the formal sense) justice - not executive whim, not financial influence and not partisan zealotry. The standard view of the rule of law is, therefore, that it preserves political legitimacy and accountability.

What is more, the UK's political agenda and decision-making process itself must achieve compliance and conformity from the regulated constituencies themselves. Undoubtedly, consensual democracy underpins the consensus-based decision-making process of the design and enforcement of corporate legal rules. As a general rule, reaching consensus, especially as far as different societal goals are concerned, is a characteristic feature of modern democracies. In addition to taking into account as broad a range of opinions as possible, legislatures are democratically elected and accountable bodies. Their members are elected as legislators, and they can be replaced at regular intervals if their constituents dislike what they or their political party are doing in the legislature. ${ }^{89}$ Yet the state must not only generate and enforce its rules in a deliberative, impartial and procedurally correct way. From an output-perspective, meanwhile, the state must also ensure that it provides solutions for the society in which it functions. ${ }^{90}$ Indeed,

86 This distinction was developed by Fritz Scharpf during the 1970s and is utilised here as it is generally a useful distinction for analysing issues of legitimacy. For a useful synopsis, see F Scharpf, Governing in Europe: Effective and Democratic? (Oxford University Press 1999) 6-10.

87 M Finnemore and S J Toope, 'Alternatives to “Legalization”: Richer Views of Law and Politics' (2001) 55(3) International Organization 743, 750 .

88 J A Grant, 'The Ideals of the Rule of Law' (2017) 37(2) Oxford Journal of Legal Studies 383, 384. Some earlier examples of this point include: J Raz, 'The Rule of Law and its Virtues' (1977) 93 Law Quarterly Review 195, 199-201; L Fuller, The Morality of Law (Yale University Press 1964) esp ch 2.

89 See e.g. J Waldron, 'Representative Lawmaking' (2009) 89 Boston University Law Review 335, 335; J Waldron, 'The Core of the Case Against Judicial Review' (2006) 115 Yale Law Journal 1346, 1361.

90 Scharpf (n 86) 10. See also, W Sadurski, 'Law's Legitimacy and "Democracy-Plus"” (2006) 26(2) Oxford Journal of Legal Studies 377, 377. 
the legislature in the UK, and elsewhere, has long been required to assess ex ante the potential effects of proposed laws through regulatory analysis 91 and wide consultation of the proposed benefits of the legal intervention, as well as parliamentary scrutiny. ${ }^{92}$ Eilis Ferran, with a paper published in 2005, opines that:

... modern theories of good governance emphasise the consultation and collaboration as techniques that can enhance legitimacy of rules and the accountability of the rule-makers. Experience in the UK company law review is certainly supportive of the legitimacy-enhancing function performed by consultation. ${ }^{93}$

In spite of Parliament being the ultimate source of legal authority, there are in practical terms significant limitations on its sovereignty because of a separation of powers. ${ }^{94}$ As the final interpreters of companies' legislation, the courts perform the important constitutional function of reconciling the legislative direction with the true meaning of the statute and, hence, its consequences for the resolution of particular company law cases. ${ }^{95}$ Of course, the judiciary, though acting in the name of the Crown, is an unelected and formally independent branch of government. While an important element of the separation of powers, it opens up the court, particularly in the context of strike-down powers, to the familiar charge that it is thus inherently democratically illegitimate. ${ }^{96}$ Clearly, there are important reasons of political thought and democratic principal that cast doubt on the propriety of giving the courts a company law-making function. Yet, it would be a mistake not to recognise that the court's political legitimacy depends precisely on its distinctiveness from political branches, albeit subject to orthodox and fundamentally similar conventions and baselines. Indeed, much of what has been said in the paragraph above is just as true of the common law, in the sense that corporate legal adjudication is framed by an important collection of input-oriented references to legal analogy, legal history, convention, the force of justice and social welfare. ${ }^{97}$ In particular, the courts tend to interpret and apply rigidly the prescriptions of the legislature, or the generalised principles deduced from a series of precedents, to individual disputes, which must be fitted into the existing body of the law. ${ }^{98}$

The common law tradition of settling disputes by reference principally to pre-existing corporate legal doctrine and legal decisions has deep and broad appeal within the

91 Petrin (n 2) 537 (and accompanying footnotes).

92 The most recent major company law reform project in the UK took place between 1998-2002 and culminated in the Companies Act 2006. The three main consultation documents were: Modern Company Law for a Competitive Economy: The Strategic Framework (DTI, URN 99/654, 1999); Modern Company Law for a Competitive Economy: Developing the Framework (DTI, URN 00/656, 2000); and Modern Company Law for a Competitive Economy: Completing the Structure (DTI, URN 00/1335, 2000). See also, Company Law, Flexibility and Accountability: A Consultative Document (DTI, URN 04/994, 2004), Annex A, 19.

93 E Ferran, 'Company Law Reform in the UK: A Progress Report' (2005) ECGI Law Working Paper 27/2005, $33<$ https://ecgi.global/sites/default/files/working_papers/documents/SSRN-id644203.pdf>.

94 For a detailed historical account of the 'pattern of attraction and repulsion' to the idea of the separation of powers, see M J C Vile, Constitutionalism and the Separation of Powers (Oxford University Press 1967) 3ff. For the less strict or rigid separation between the branches than the orthodox account would allow, see A Kavanagh, 'The Constitutional Separation of Powers' in D Dyzanhaus and M Thorburn (eds), Philosophical Foundations of Constitutional Law (Oxford University Press 2015) 221.

95 Allan (n 21) 157.

96 Waldron (n 89) 1346; M Tushnet, Weak Courts, Strong Rights: Judicial Review and Social Welfare Rights in Comparative Constitutional Law (Princeton University Press 2008) ch 2. Cf R H Fallon, Jr, 'The Core of an Uneasy Case for Judicial Review' (2008) 121 Harvard Law Review 1693.

97 P Winfield, 'Public Policy in the English Common Law' (1929) 42 Harvard Law Review 76, 76.

98 See sources cited in nn 22-23 above (and accompanying text). 
tradition of liberal political thought. For H L A Hart, the judge's role is best analogised to the 'delegated rulemaking power [of] an administrative body', 99 In this model, courts have authority to make, or amend, rules for unregulated cases and are instructed to do so with reference to the principles and standards established in the authoritative provisions. Hart further argued that 'legal decision-making does not proceed in vacuo but always against a background of a system of relatively well established rules, principles, standards, and values'. 100 Of equal relevance are relatively recent accounts about the democratic foundations of common law reasoning: forensic, transparent, reflective of historical social values, rooted in a concept of individual rights and so forth. ${ }^{101}$ Others have sought to show that judge-made law can itself become a valuable channel of political participation and thus to agitate for legal change, especially for those who are marginalised and disempowered in the normal political process. ${ }^{102}$ From the output perspective, the legal decisions generated by the courts must cohere with the ongoing expression of public values. This point is well articulated by Lord Nicholls of Birkenhead, who remarked obiter that, "[f] or centuries, judges have been charged with the responsibility of keeping this [the common law] abreast of current social conditions' ${ }^{103}$ Accordingly, if a court gets out of sync with the legal and political culture, its pronouncements risk being ignored or overruled by the legislature. So understood, this awareness of the political context is an important component of a court's output-legitimacy in company law cases.

\subsection{THE POLITICAL LEGITIMACY OF MARKET-BASED REGULATION}

From the analysis above, it is evident that the UK's company law, which is a product of social organisation, necessarily, therefore, derives authority and political legitimacy from fundamental prerequisites of authoritative adjudication and legislation in addition to those relating to a judge's or legislature's formal entitlement to adjudicate or legislate. These prerequisites essentially rest on public democratic criteria and accountability, such as deliberative, impartial and appropriate process-oriented 'inputs'. Simultaneously, this understanding of legitimacy is instantiated through rule-based 'outputs' that aims to protect both shareholders and, to an extent, the public interest in the effective functioning of wealth-generating companies. ${ }^{104}$ On the contrary, market-based regulatory formations typically combine the institutional structure and function of state company and capital markets' rulemaking with the narrow incentives and interests of the most important ruleusers in the marketplace. Accordingly, there might be a problem with this article's attempt to inscribe the dominant understanding of legitimacy in regulation. The understanding might not actually work as a general structuring principle for market regulatory bodies because their institutional and administrative workings do not readily or plausibly sit within conventional patterns of the rule of law, consensual democracy and accountability to the courts. No doubt, the quality of outcomes-focused or outcomes-based approaches to the exercise of regulatory power, as we will see, is less contentious because of apparent technocratic or elite expertise, efficiency gains and purposive flexibility. On the input side,

99 H L A Hart, The Concept of Law (Clarendon 1967) 132-133.

100 H L A Hart, 'American Jurisprudence through English Eyes: The Nightmare and the Noble Dream' (1977) 11 Georgia Law Review 969, 979.

101 See e.g. Allan (n 21) 185. For a US commentary on this point, see e.g. C E Carpenter, Jr, 'The No-citation Rule for Unpublished Options: Do the Ends of Expediency for Overloaded Appellate Courts Justify the Means of Secrecy?’ (1998) 50 Southern California Law Review 235, 248.

102 A Kavanagh, 'Participation and Judicial Review: A Reply to Jeremy Waldron' (2003) 22(5) Law and Philosophy 451.

103 Re Spectrum Plus Ltd [2005] 2 AC 680 at [32].

104 See Committee on Company Law Amendment (CMD 6659 1945) at [130]. 
however, the practical operation and rule control of these alternative regulatory systems takes the risk of being at odds with democratic or policy-based criteria, as well as a substantial body of academic theory and, accordingly, is more likely in practice to undermine and inhibit their perceived authority and legitimacy.

Due to the micro-institutional identities and drivers of the UK's respective regulatory formations, there is not one but many versions of rulemaking bodies, which tend to comprise varying iterations of institutional-functional formality and invariably engage distinct linear points between the public/private poles. ${ }^{105}$ Even if the argument at play here does not pin down a regulator archetype, it remains tempting to view the varied regulatory authorities charged with drafting and enforcement powers as having been formed by or being connected to the state. Consider, first, the FCA, which, as the UK's official listing authority, is (and always has been) an independent body created by statute, namely, the Financial Services and Markets Act 2000. ${ }^{106}$ The FCA is responsible for writing and enforcing the Listing Rules of the London Stock Exchange, which have the status of delegated legislation. In this regard, the body is accountable to the Treasury and to parliamentary scrutiny. In contrast, the FRC is at the present moment in time formally a non-governmental body that is constituted on a private-sector basis in the form of a company by guarantee. However, public administrative dynamics are inscribed informally insofar as the British government confers statutory authority under the Companies Act 2006 to update the Corporate Governance Code. ${ }^{107}$ Simultaneously, its chair and deputy chair are appointed by the Secretary of State for Business, Energy and Industrial Strategy. In spite of the enduring refusal of successive UK governments to displace the perceived prerogative of the FRC to determine the substantive content of the Code, it now seems likely that it will be replaced with an independent statutory regulator with new powers, accountable to Parliament, and named the Audit, Reporting and Governance Authority (ARGA). ${ }^{108}$ Finally, the Panel on Takeovers and Mergers is a private body, similar to the FRC, upon which statutory functions in relation to takeover bids have been conferred under the Companies Act 2006. ${ }^{109}$ This means that the rules set out in the Code have a statutory basis and apply to takeover bids or merger transactions of public and private companies in the UK. On this basis, the Panel and the Department for Business, Energy and Industrial Strategy (BEIS) coordinate loosely with one another on important issues relating to takeover policy and regulation. Overall, the institutional and functional approach to determining 'public-ness' of the regulator constituencies, conceived as the domain of the state, is ultimately conducive to presenting these regulatory forms as expressly authorised and structured by formal governmental interference or influence in a strictly technical sense.

To many, this institutional and functional analysis as a general structuring principle for market-based regulators may portend the end of the story. Is the body in question part of the government? And is the process, conduct, or decision in question one typically public or discharged by government? In short, most of these regulatory bodies have evolved into agencies that have a more clearly defined public dimension. However, a

105 M Moore and M Petrin, Corporate Governance: Law, Regulation and Theory (Palgrave 2017) 22.

106 S 73A. The Financial Services Act 2012 amends the FSMA 2000 to formally create the FCA.

107 Companies Act 2006, part 42. See the Statutory (Amendment of the Companies Act 2006 and Delegation of Functions, etc) Order 2012.

108 See BEIS, 'Audit Regime in the UK to be Transformed with New Regulator' (Press Release, March 2019) <www.gov.uk/government/news/audit-regime-in-the-uk-to-be-transformed-with-new-regulator>.

109 Companies Act 2006, ss 942-965. As amended by the Companies Act 2006 (Amendment of Schedule 2) (No 2) Order 2009. 
closer inspection of how these alternative regulatory bodies both organise and operate (relative to the UK's substantive company law-making bodies) raises significant doubt about what it is that gives them their input-legitimacy and in what ways they can be held accountable. Although the state often seeks to achieve its regulatory objectives by conferring a mixture of statutory functions and limited delegated powers whilst simultaneously maintaining formal oversight of the regulation, in doing so it takes the risk that the regulator's practical inner workings and control of the rules may bias the rule detail and rule orientation in favour of primary rule-users who are subject to its regulatory authority. ${ }^{110}$ In particular, certain of the most influential rule-making bodies in UK corporate governance, such as the FRC and the Takeover Panel, are controlled by market participants, with a majority of appointed board members from the business and accounting worlds and, at best, only a minority of delegated representatives from other regulators or government. ${ }^{111}$ Similarly, when we think about how the Takeover Panel's executive, for example, staffs itself, it becomes difficult to ignore the fact that it comprises limited full-time staff, with mainly secondees drawn from a spread of institutional shareholder, corporate practitioner and other financial institutions within the Panel's regulated community. What is more, charging fees and levies to the firms and market actors who are subject, or have regard to, or benefit from market-based rules and enforcement typically funds these regulatory bodies. ${ }^{112}$ By providing the market with such a key role in regulatory control and funding we might have valid public choice concerns that the rules will become tilted toward the financial institutions that are broadly representative of the City establishment's institutional shareholder and associated professional communities. ${ }^{113}$ Ultimately, the investigation in this subsection turns on the survival and operational public/private distinction of the regulator constituencies and, once identified, it is tempting to the see the market's practical input into the design and enforcement of various rules and practices as unavoidably weighted towards the interests of (private) business and market participants rather than the (public) formal and procedural prerequisites of the rule of law.

Correspondingly, in spite of the separation of powers being a pervasive feature of the UK's exercise of legal power to form and tailor the rules of corporate life, ${ }^{114}$ there are valid reservations about an equivalent system of 'checks and balances' in the realm of market regulation. ${ }^{115}$ The continuation of a democratic 'overhead', described above, purportedly extends a form of democratic control from more traditional institutions over the new unelected bodies. Yet, we have seen the attempt to extend democratic controls takes the risk of being undermined by the market's presumptive and actual control of the exercise of regulatory power. ${ }^{116}$ Moreover, if we look inside the respective bodies' particular constitutional structures, and the participative procedures, the problem of regulatory capture, and so less accountability, risks feeding through into institutional design. Let us consider the perceived concerns in a little more detail. On the Takeover

110 Kershaw (n 1) 869.

111 For current board membership, see <www.frc.org.uk/about-the-frc/structure-of-the-frc/frc-board/frcboard-members >; <www.thetakeoverpanel.org.uk/structure/panel-membership $>$.

112 See, for example, <www.frc.org.uk/about-the-frc/funding>; <www.fca.org.uk/firms/fees/how-we-calculateannual-fees $>$; <www.thetakeoverpanel.org.uk/the-code/fees-and-charges? $>$.

113 Davies (n 2) 714.

114 See e.g. E Barendt, 'Is there a UK Constitution?' (1997) 18 Oxford Journal of Legal Studies 137; E Carolan, The New Separation of Powers: A Theory of the Modern State (Oxford University Press 2009) 18.

115 See e.g. F Vibert, The Rise of the Unelected (Cambridge University Press 2007) ch 4.

116 Of course, many valid arguments suggest that the regulator constituencies operate under the continuing threat of state intervention and influence. On this point, see e.g. Cheffins (n 40) 375. Cf Moore (n 5) 170. 
Panel, for example, the Panel, its Executive, and various Committees, subdivide substantive responsibilities for writing, adjudicating and enforcing the Code. The informal ex ante rulings of the Hearings Committee can be appealed to the independent Takeover Appeal Board. ${ }^{117}$ Similarly, although the FCA is constituted, directed and controlled by its board, comprising executive and non-executive directors, it delegates certain functions/powers to the chief executive officer and/or several committees (e.g. auditing, risk and strategy). Any company may apply to an independent Upper Tribunal for a review of any of the rules made by the FCA or to check whether it came to the correct view of the law. ${ }^{118}$ There is, taken together, apparently a latent, but embryonic, separation of powers of, and within, the distinct branches of the Takeover Panel and the FCA. However, the fact remains that almost all of the regulator constituencies, however formally or practically partitioned, tend to be comprised of a relatively homogeneous group of people with industry knowledge, and their careers tend to follow the 'revolving door' process, itself a potential means of capturing the regulator through implicitly biasing the regulators' incentives towards the regulated activity. ${ }^{119}$ The concept of capture is problematic because it conveys 'a sense of illegitimate expropriation, performed by one powerful group over others, of the resources we might have thought were provided for public interest goals'. ${ }^{120}$ A closer inspection of the practices inhering within the regulator constituencies, therefore, calls into question the perceived validity and rigour of the separation of powers of, and within, the regulator constituencies. In consequence, this understanding might explain why the subsequently produced rules, including board rules, are heavily pro-shareholder. ${ }^{121}$

Finally, a point that has been lurking in the shadows of the analysis above should be brought to light. It is that these alternative regulatory systems generate a reasonably high level of outcome-oriented compliance and conformity of, and within, corporate life, despite input-legitimacy and democratic concerns. How might these extensive and rigorous rule-sets function effectively and command the respect of all? Properly understood, the market rule-making bodies that sustain contemporary corporate activity are characterised by a political outlook and rule choice that involve norm formation targeted exclusively at market participants as opposed to as broad a range of individuals as possible. Arguably, as Marc Moore and Martin Petrin concisely note, ' $[\mathrm{t}]$ his has significant implications in terms of how these bodies understand the proper bounds of their regulatory remit, as well as in relation to the scope of public interest or distributional concerns'. ${ }^{122}$ Consider, and compare, for example, the review process of the Company Law Review's legislative reform project with the equivalent means by which market bodies create and apply

117 The Appeal Board's Chairman and Deputy Chairman are appointed by the Master of the Rolls and will usually have held high judicial office. The other members of the Board are appointed by the Chairman or Deputy Chairman and will usually have relevant knowledge and experience of takeovers and the Takeover Code. No person who is or has been a member of the Code Committee of the Takeover Panel may simultaneously or subsequently be a member of the Board. The current membership of the Takeover Appeal Board is available here: <www.thetakeoverappealboard.org.uk/membership/>.

118 FCA, Complaints against the regulators: The Complaints Scheme, 2016 <www.fca.org.uk/publication/corporate/complaints-scheme.pdf>.

119 The pioneering work on capture theory is G Stigler, 'The Theory of Economic Regulation' (1971) 2(1) Bell Journal of Economics and Management Science 1. For a superbly concise account, see T Prosser, 'Theorising Utilities Regulation' (1999) 62(2) Modern Law Review 196, 200-206.

120 L G Baxter, “Capture” in Financial Regulation: Can We Channel it toward the Common Good?’ (2011) 21(1) Cornell Journal of Law and Public Policy 175, 176. For a useful account of regulatory capture theory, see Prosser (n 119) 200-206.

121 Davies (n 2) 714-715.

122 Moore and Petrin (n 105) 22. 
regulatory solutions. The Company Law Review consulted extensively and was subject to rigorous parliamentary scrutiny on its self-identified 'scope' of company law, however ultimately channelled into the deeper shareholder rights bias in the UK's company law. Yet, the formal consultation process of the Takeover Panel's Code Committee, for example, introduces or amends any rules of the Code through comparatively marginal, if useful, dialogue mainly (although by no means always) with all relevant 'deal insiders'.123 In spite of making available all responses for public inspection, the presumption and expectation that market participants should address and resolve the problems of their own making, although producing output-legitimacy in a strictly limited sense, risks being less openly and effectively questioned by the general public and in the public policy arena. ${ }^{124}$ This is in spite of the fact that the Panel, conceived as functionally silent or neutral in respect to distributional concerns extraneous to considerations of shareholder welfare, ${ }^{125}$ is nevertheless likely to, and does, produce significant and extensive socially normative outcomes. ${ }^{126}$

\subsection{FROM POLITICAL TO TECHNOCRATIC LEGITIMACY}

Based on the above analysis, it might seem misplaced to concentrate upon dominant accounts of modern democratic criteria, principally because the operation and outlook of market regulatory bodies lie somewhat outside standard legitimacy mechanisms. An apparently weak form of input-legitimacy, and a weighted outcome-legitimacy, relatively speaking, may scarcely come as a new or exciting truth to proponents of market-based regulatory regimes. ${ }^{127}$ In neoliberal discourse, political legitimacy and democratic accountability are relatively important prerequisites for regulator constituencies. However, the apparent availability of a greater degree of professional expertise and marketdeterminable practices (relative to standard public law-making bodies) are often claimed to invoke a rival conception of legitimacy, which supports and nourishes both the general acceptability and the actual effects of regulation in two distinct ways. ${ }^{128}$ First, there is the apparently technocratic or practical criteria that generates regulatory solutions in the UK, whereby predominantly financial and legal intermediaries design and enforce rules in an apparently politically neutral context, ${ }^{129}$ which is shaped by a set of professional ideals of what regulatory value judgements are economically efficient from the perspective of the marketplace. ${ }^{130}$ The concept of technocracy maintains the perceived apolitical prerogatives of the regulator, which then justifies the public trust that is placed in them to exercise significant and extensive regulatory power on a non-arbitrary basis outside of the standard 'checks and balances' of the democratic state framework. Second, these regulatory formations are reputed to closely reflect the endogenous preferences of private business and market participants generally rather than having any social-

123 For a list of the respondents who submitted responses on a non-confidential basis to arguably the most significant Takeover Panel review in the previous decade, see the Takeover Panel, Review of Certain Aspects of the Regulation of Takeover Bids (June 2010) <www.thetakeoverpanel.org.uk/wpcontent/uploads/2008/11/2010-22.pdf>.

124 Prosser (n 119) 199. See also Moore (n 5) 170-172.

125 Moore (n 5) 172.

126 See Datafin (n 41) as per Lord Donaldson MR at 838.

127 Black (n 33) 1042.

128 The following two points on the general acceptability of market bodies follow closely the concise analysis in Moore (n 5) 170-174. See also, Prosser (n 119) 197-199.

129 P Mair, Ruling the Void: The Hollowing Out of Western Democracy (Verso 2016) 6.

130 Morgan (n 42) 507. See also, B Gilley, 'Technocracy and democracy as spheres of justice in public policy' (2017) 50(9) Policy Sciences 9, 14-16. 
distributional implications in their own right. Accordingly, the respective rule systems could be said to derive their customarily regarded regulatory legitimacy from market compliance and conformity, insofar as they commonly seek to reflect rather than displace the expected economic interests of the advisors and of their clients generally.

However, it is important to sound a note of caution against these two reputed sources of the continuing survival and legitimacy of regulator constituencies in the UK. First, the regulatory ideal, that is a standard (or, perhaps, set of standards) to which private or professional arrangements of market forms are said to conform, does not relieve us from the need to look at the evidence for this claim. Clearly, the existence of empirically dispositive evidence to support this account about optimal market solutions in corporate and financial markets regulation is deeply ambivalent. ${ }^{131}$ Equally clearly, descriptive accounts of economic efficiency in this regard tend to be conflated with normative values, or are the product of unanalysed assumption and borrowing and the cascading of such borrowings. Rather, the limits of markets as regulatory mechanisms for constraining socially suboptimal behaviour and outcomes are numerous and well documented. On this basis, the most one could say is that 'although a perfect market is superior to an imperfect legal rule, an imperfect market may be either better or worse than an imperfect legal rule [emphasis added]'. ${ }^{132}$ It follows that in some, but far from all, areas of corporate activity, market-based regulation might prove to be the most economically efficient mode of regulation, while in others the substantive law might be relatively more effective in this regard. In addition to a questionable inscription of economically efficient ideals in technocratic rule formation, earlier discussion, meanwhile, has queried whether the market-based regulator's claim to political neutrality or impartial pragmatism is necessarily valid. No doubt, while neutrality of method might be difficult to achieve, the regulator constituencies tend to maintain the position that partiality is possible to avoid: technocrats avoid value claims, reject political or ideological predispositions, and often receive general acceptability in the marketplace. One problem with this approach is that expert knowledge is not necessarily neutral, especially when we have observed that regulation may be captured by powerful vested interests, or at least, in light of a weighted shareholder presence in existing regulatory solutions, is not always used for neutral purposes. Ultimately, therefore, one needs to be wary of such broad-brush claims about the plausible, although speculative, legitimacy of the regulator through apparently neutraltechnocratic and pragmatic expertise.

The second claim about legitimacy of market regulatory formations refers, it will be recalled, to the single goal of protecting and advancing economic efficiency (rather than social welfare-enhancing regulatory solutions) in the marketplace, which, in turn, generates compliance and conformity, insofar as the respective rule systems purport to crystallise the expected economic interests of industry and market participants generally. Certainly, the constituent rules and practices of, say, the Takeover Code or the Corporate Governance Code often, and understandably, reflect the commercial or political interests of financial and legal intermediaries that might otherwise emerge through private ordering, were the costs of making adequate provision for all possible contingencies sufficiently low. Simultaneously, targeted norm formation also means that some of the most important market-based rules apply, either formally or in practice, only to a small, but important, subset of the total population of companies regulated under the Companies Act 2006 and earlier legislation, i.e. those which are listed on the Main Market

131 J Armour, 'An Economic and Jurisprudential Genealogy of Corporate Law' (2002) 61(2) Cambridge Law Journal 467, 468.

132 M A Eisenberg, 'Bad Arguments in Corporate Law' (1990) 78 Georgetown Law Journal 1551, 1551-1552. 
of the London Stock Exchange, and often only to those which have chosen a premium listing. In some sense, if one were to restrict the analytical lens to the exclusive mission goal and targeted audience, explained above, there are valid arguments in favour of describing the UK's approach to company and financial market regulation as legitimate, provided that the system applies only to the areas of regulation and does not have any wider socially determinative effect in its own right. Yet, the Takeover Panel or the FCA, for example, in remaining deliberately and consistently silent when it comes to surrounding public policy debate about the attraction or otherwise of their overall social effect, while simultaneously providing for a formal and enduring weighted shareholder presence in corporate governance, could nonetheless have one unintended consequence. Specifying, it is likely that this task-driven method lends significant tacit political or ideological support to the idea that protecting and empowering shareholders is inherently democratic, although not chosen or necessarily supported by the public at large, or even open to meaningful discussion among them.

\section{Conclusion}

At the beginning of this article, two objectives were specified: the first concerned the relationship and interaction between the UK's substantive company law and its marketbased regulation; the second explored the legitimacy of market-based regulation in light of its potential to mould and influence the content of legal rules where the state is passive or the state remains active, but the law is indeterminate. As to the first, although the UK's company law provides the legal ecology to facilitate productivity organised in companies by reducing agency costs between participants, market-based regulators, meanwhile, have become increasingly important to the design and enforcement of basic 'rules of the game' between market participants by reducing socially suboptimal behaviour and outcomes. This is assuredly the case where the British state has deferred law-making competence to the market because it neither has the time, nor the interest, nor the expertise. However, where there is proactive intervention or a role for law, the subsequent legal rules are often, and understandably, viewed as somewhat limited in effectiveness and outlook. This is in turn likely to have a number of direct or practical implications, not least the dampening effect on the perceived impact of company law's weighted shareholder presence. On this basis, in order to interpret and apply the rules in question, policymakers or practitioners might be tempted to draw upon heavily pro-shareholder, if more workable, guidance provided in market-based regulatory instruments. There is already some evidence of such an approach. As to the second inquiry about legitimacy, two points can be made. One is that the main problem about market-based regulation in this regard is that it too readily transforms controversial objectives and political issues into the question of rulemaking for hybrid state/market regulators. In this way, it takes critical decision-making powers out of the public process. Since that process is the only way the general population is able to engage, however indirectly, in the shaping of law, this is arguably contentious from a democratic legitimacy perspective. The other is that these market-based regulators do not readily or plausibly lend themselves to dominant political narratives and democratic criteria, which customarily nourish and support procedural and substantive legitimacy of state interventionist techniques in company lawmaking. Simultaneously, the deployment of a rival conception of legitimacy, conceived as neutral technocratic expertise and market determinable practices to support both the general acceptability and the actual effects of regulation, is arguably contentious because of public choice concerns about regulatory capture and the fact that the general 
acceptability or otherwise of market-based rules is typically limited to the marketplace, despite the wider socially determinative impact on the population at large.

This subject of enquiry is timely and relevant for two reasons. First, while this article focuses upon the UK corporate regulatory framework and potential challenges, questions about the relationship between regulatory instruments and techniques, and the relative legitimacy of law-making in company law and financial regulation, are ones that are of general interest to policymakers around the world operating at national, regional and international levels. The internationally mobile character of much modern business operations make it important for states and regions to benchmark their 'mix' against that chosen by others and to ask whether they have achieved a combination that is commercially attractive and likely to promote the contribution of the corporate sector to the overall economic and social well-being of society. Second, the article's findings have significant ramifications for continuing international debates on the devolution of specific functions to market-based regimes accompanied by new types of public-private interactions. Many open questions remain, theoretically and practically, about these changes and their implications for the legitimacy of governance processes. The present article, accordingly, develops this important strand of competing thought by framing the political and constitutional case that market-based regulation risks undermining the rule of law and its democratic potential, with the effect of exacerbating corporate threats to public interests. In doing so, it moves forward the democratic and political case for representative law-making in company law beyond the contemporary neoliberal rationales centred on the relative value of market competence. 
